\title{
Grade R teachers' experiences with the implementation of the mother-tongue-instruction policy for pre-reading skills in Lesotho
}

\begin{tabular}{|c|c|}
\hline \multicolumn{2}{|c|}{$\begin{array}{l}\text { Authors: } \\
\text { Arone C. Koloti }{ }^{1} \\
\text { Thuthukile Jita }\end{array}$} \\
\hline \multicolumn{2}{|c|}{$\begin{array}{l}\text { Affiliations: } \\
{ }^{1} \text { Department of Curriculum } \\
\text { Studies, Faculty of Education, } \\
\text { University of the Free State, } \\
\text { Bloemfontein, South Africa }\end{array}$} \\
\hline \multicolumn{2}{|c|}{$\begin{array}{l}\text { Corresponding author: } \\
\text { Thuthukile Jita, } \\
\text { jitat@ufs.ac.za }\end{array}$} \\
\hline \multicolumn{2}{|c|}{$\begin{array}{l}\text { Dates: } \\
\text { Received: } 19 \text { Nov. } 2020 \\
\text { Accepted: } 18 \text { Aug. } 2021 \\
\text { Published: } 28 \text { Sept. } 2021\end{array}$} \\
\hline \multicolumn{2}{|c|}{$\begin{array}{l}\text { Research Project Registration: } \\
\text { Project Number: } \\
\text { TTK170405225946 }\end{array}$} \\
\hline \multicolumn{2}{|c|}{$\begin{array}{l}\text { How to cite this article: } \\
\text { Koloti, A.C. \& Jita, T., 2021, } \\
\text { 'Grade R teachers' } \\
\text { experiences with the } \\
\text { implementation of the } \\
\text { mother-tongue-instruction } \\
\text { policy for pre-reading skills in } \\
\text { Lesotho', South African } \\
\text { Journal of Childhood } \\
\text { Education } 11(1) \text {, a957. } \\
\text { https://doi.org/10.4102/ } \\
\text { sajce.v11i1.957 }\end{array}$} \\
\hline \multicolumn{2}{|c|}{$\begin{array}{l}\text { Copyright: } \\
\text { (C) 2021. The Authors. } \\
\text { Licensee: AOSIS. This } \\
\text { is licensed under the } \\
\text { Creative Commons } \\
\text { Attribution License. }\end{array}$} \\
\hline \multicolumn{2}{|l|}{ Read online: } \\
\hline 口ifin: & $\begin{array}{l}\text { Scan this QR } \\
\text { code with your } \\
\text { smart phone or } \\
\text { mobile device } \\
\text { to read online. }\end{array}$ \\
\hline
\end{tabular}

Background: Over the years, the majority of the Basotho nation and many countries have known Lesotho as a country which has Sesotho and English as the only spoken languages and as medium of instruction in schools. Whereas, in reality, Lesotho has many spoken languages. Many tribes have their own spoken languages which, hitherto, have not been considered in the education sector of Lesotho.

Aim: This article aimed to demonstrate the Lesotho Grade $\mathrm{R}$ teachers' experiences with the implementation of the mother-tongue-instruction policy in teaching pre-reading skills.

Setting: This study was conducted in Lesotho at three different schools. Three Grade R teachers were chosen and studied in their respective classrooms.

Methods: Employing qualitative research methods in this study, the multiple case study research design was used to explore the reality of classroom teaching practices. Document analysis, non-participatory classroom observation and semi-structured interviews and thematic content analysis were employed to generate data.

Results: Teachers in early childhood education (ECE) do not implement medium of instruction policy appropriately because they are not well-informed about it.

Conclusion: Grade $\mathrm{R}$ teachers are willing to operationalise the mother-tongue-instruction policy effectively, even though they do not have adequate knowledge of the policy.

Keywords: early childhood; Grade R teachers; Lesotho education; mother-tongue instruction; policy implementation; pre-reading skills.

\section{Introduction}

Implementing mother-tongue-instruction policy in early childhood education (ECE) (0-8 years) in schools is encouraged in many countries across the globe, such as Sri Lanka, Malaysia, the Philippines, Ghana, South Africa and Lesotho (Alieto 2019; Brock-Utne 2012; Lesotho Ministry of Education and Training [MOET] 2013a; Mashiya 2011;Navarro et al. 2016), even though it poses many challenges for the teachers because many countries have more than one spoken language (Bongco \& David 2020). However, English as a language of teaching is mostly favoured globally by communities in which it is a first additional (second) spoken language. This is because it is believed to create opportunities for learners to achieve academic goals and better employment (Ekanjume-Ilongo 2015; Gumbi \& Ndimande-Hlongwa 2015; Lenyai 2011). Moreover, English language serves as the gatekeeper for multiple opportunities used as a means for communication with the rest of the world, and people believe that the best way to learn it is to use it as a language of instruction (Alieto 2019; Brock-Utne 2012; Mashiya 2011). Learners who are not competent in English language are classified as illiterate and/or incompetent, even when they can read proficiently in their mother tongue (Lenyai 2011; Navarro et al. 2016). As researchers in this study, we understand that teachers often do not prepare learners adequately to learn in their home languages (HLs) because they do not implement policies as intended by the policymakers, especially in ECE.

Evidently, the majority of learners from as early as in ECE worldwide do not receive classroom instruction in their mother tongue, especially in the countries which were once colonised (Malebese, Tlali \& Mahlomaholo 2019; Okebukola, Owolabi \& Okebukola 2013). For example, Brock-Utne (2012) stated that English is used as language of instruction in Malaysian schools, a

Note: Special Collection: Early Childhood Development in Theory and Practice. 
country which was a British colony, as is also the case with Lesotho. Okebukola et al. (2013) found that in Nigeria, English is used alongside HLs from primary 1 through primary 3 in order to introduce the learners to English language in the early grades. In many countries, learners learn literacy skills in one or two dominant languages that are rarely or not used outside the school environment; languages that they even hardly understand in the classrooms. They are often taught by teachers who also do not fully understand the additional languages used as medium of instruction (Ekanjume-Ilongo 2015). Contrary to many of these findings, in a study of 10 schools in the Gauteng province in South Africa, Lenyai (2011) found that learners were not taught in English in Grade 1 and that English as a subject was rarely taught and was not dominant as language of learning and teaching (LOLT) in Grade 2 and 3 because teachers favoured $\mathrm{HL}$ as the medium of teaching in these grades.

In several countries, English curriculum dominates other curricula (Vilches 2018). According to Gumbi and NdimandeHlongwa (2015), the languages that were used as LOLT in the colonial era in South Africa are still the dominant language of instruction in many schools despite establishment of the multilingual policy in 1996. The Curriculum and Assessment Policy Statement (CAPS) stipulates that all learners have a right to be taught in their native language up to Grade 3 (Cekiso, Meyiwa \& Mashige 2019; Department of Basic Education [DBE] 2011; Lenyai 2011). Teachers often lack proficiency in the language of instruction which is a HL (Cekiso et al. 2019). It seems therefore that language policy supporting mother tongue instruction is not implemented desirably in many countries because practice has not fully changed in schools (Okebukola et al. 2013). The policy has no effect in the classroom, yet research shows that mother tongue instruction lays a good language foundation, such as phonological awareness (Nishanthi 2020; Vilches 2018). However, when teachers are positive about policy changes, they aspire to implement what they understand about it because they believe that it is important to do so (Bongco \& David 2020; Chimbi \& Jita 2019).

Majority of the learners who are taught in their mother tongue in preschool and foundation phase grades have better learning opportunities and perform well academically as they grow up (Alieto 2019; Mashiya 2011; Navarro et al. 2016). They have a better chance of developing critical thinking and literacy skills, and understanding learning activities because they are taught in a language that they speak at home, a language which their parents can understand and can contribute to their learning process (Cekiso et al. 2019; Lesotho MOET 2013a). Mother tongue helps them to learn pre-reading skill and activities with enthusiasm and connect with classroom conversation because they are taught in a language they and their families are familiar with, and facilitates learning other languages (Nishanthi 2020). It connects them with their culture and local environment, and therefore they are able to associate sounds with symbols they see (Cekiso et al. 2019). Kao and Mzimela (2019) asserted that learners enter school with home background knowledge of print and the literacy skills and activities which Grade $\mathrm{R}$ learners need to learn include letter recognition, naming objects, singing, and reciting rhymes that develop their phonological awareness. Learners enjoy engaging with reading materials which they understand and learn reading skills even though in most cases teaching and learning materials in mother tongue are insufficient (Cekiso et al. 2019).

The problem of not understanding language of instruction leads to poor-quality education (Cekiso et al. 2019; Malebese et al. 2019). However, even in the countries where there are policies which advocate mother tongue emergent-literacy instruction, some schools do not implement them in the approved manner in ECE, especially in Grade R as in Lesotho (Hallam et al. 2015). The number of factors which slow down and/or determine successful implementation of mothertongue-instruction policy include teachers' ineptitude, school leadership ineffectiveness and limited resources (Cekiso et al. 2019; Nishanthi 2020).

Teachers play a key role in the implementation of education policies, even though in many occasions they are neglected in the process of designing them (Bongco \& David 2020; Vilches 2018). Dube and Jita (2018) and Hudson, Hunter and Peckham (2019) highlighted that policy implementation fails because there is inadequate collaboration between policymakers and policy implementers. Teachers are the most important people in policy and curriculum implementation because they have a significant influence on how the changes made or suggested in the policy are put into reality in the classrooms (Navarro et al. 2016). The reality is that most often, teachers and school leaders are not well informed about the changes made in the policy because they are rarely consulted (Hudson et al. 2019; Samson \& Charles 2018). Sometimes, some teachers do not implement policies appropriately because of their ignorance, whilst others lack experience of engaging with policy. Most often, majority of the teachers are not provided with resources (eds. Mueller \& File 2019). As a result, it is of utmost importance to, without negligence, start with changing the personnel mindset (such as of teachers) prior to and during policy dissemination and to provide them with policy documents and teaching resources to make them active implementers of the policies.

Sesotho and English have been recognised as the only two official languages of Lesotho as this is enforced in the Constitution of the country (Lesotho Government Constitutional Matters [LGCM] 1993). Sesotho is the first language spoken by the majority of the nation, while English is the second language (Ekanjume-Ilongo 2015). Teachers relied on the Early Childhood Care and Development (ECCD) Curriculum 1998 for teaching literacy and little is known about their classroom practice. This study is envisioned to highlight teachers' experiences when implementing mother-tongue-instruction policy in teaching 
pre-reading skills in Grade R classrooms of Lesotho. This is because to the best knowledge of the researchers limited studies on the subject have been conducted in Lesotho since the National Policy for Integrated Early Childhood Care and Development (IECCD) was developed in 2013 (Lesotho MOET 2013a). The mother-tongue-instruction policy for ECE is fused in the national policy for IECCD. The policy outlines that learners be taught in their native language in early childhood (Lesotho MOET 2013a). Therefore, the study sought to answer this research question: What are the Grade $\mathrm{R}$ teachers' experiences with the implementation of the mother-tongue-instruction policy in Lesotho?

\section{Theoretical framework}

This study was guided by the Vygotsky's Social Interaction Theory. For instructional practice, this theory plays an important role to ensure engagement of teachers in the initial stage of policy design (Blake \& Pope 2008; Hudson et al. 2019). This helps them when implementing education policy, especially mother-tongue-instruction policy, to understand the phenomena by themselves, understand the teaching process and engage in the same style of teaching as desired by the policymakers. The teachers' interaction with the community, in this case policymakers, helps them to gain and understand new knowledge (Nulden \& Scheepers 2020). Vygotsky referred to this as the zone of proximal development (ZPD), which is the level at which teachers need help from those who possess more knowledge than themselves. These others were identified by Vygotsky as the more knowledgeable others (MKOs) (Pishghadam \& Ghadiri 2011). This notion suggests that policymakers should team up with teachers and facilitate policy implementation to improve the quality of education, especially language of instruction policy, as according to Vygotsky's Cognitive Development and Social Development Theory, people work and learn better in collaborations (Pishghadam \& Ghadiri 2011).

\section{The research approach}

This study was underpinned by the interpretive paradigm because it gave us the opportunity to study a phenomenon in depth and as it existed in its natural context (Leedy \& Ormrod 2013; Mukherji \& Albon 2015). This paradigm was further chosen because it allowed us to interpret the world and/or reality through the perceptions and experiences of the research participants (Thanh \& Thanh 2015). In this study, the perceptions and experiences of the research participants regarding their challenges and opportunities were projected to provide data that would give us an understanding of the problem under study. We intended to construct our understanding from reality via data gathered from individual participants, as Creswell and Creswell (2018) stated that research in the interpretive paradigm depends on the views of the participants.

We chose to use the qualitative research approach because the interpretive paradigm interconnects harmoniously with qualitative research methods (Thanh \& Thanh 2015). This qualitative research sought rich data in order to assist us to fully understand the context of the study and the research problem regarding the Grade $\mathrm{R}$ teachers' experiences with the implementation of the mother-tongue-instruction policy. Qualitative research facilitated the investigation of teachers' experiences by collecting, analysing and interpreting their comprehensive stories and the visual data to gain insights into the research problem (Nolan, Macfarlane \& Cartmel 2013).

As the choice of research design and methodology depends on the research questions (Creswell \& Creswell 2018), it was appropriate to use a case study research design using three Grade R classrooms in Lesotho as research sites. A case study design is one of the qualitative research methods (Thanh \& Thanh 2015), which was adopted to explore different backgrounds and experiences of Grade $\mathrm{R}$ teachers to implement mother-tongue-instruction policy in their classroom. Yin (2018) stated that in a case study research design, the researcher is able to study the phenomenon systematically and understand it deeply in its context. Therefore, a case study design of three Grade R teachers in their respective classrooms was adopted.

\section{Population and sampling criteria}

The population of the study comprised qualified teachers of Grade R (reception) classes of Lesotho who teach early literacy. We used pseudonyms to protect participants' identity and research sites. Table 1 provides summaries of the biographical data of the participants.

Purposive sampling was employed to select the three Grade $\mathrm{R}$ teachers. This sample size was manageable and offered us an opportunity to grasp the meaning that participants give to their experiences, and to understand their behaviour (Daniel 2016; Leedy \& Ormrod 2013; Mukherji \& Albon 2015).

The three participants were of different ages, but of the same gender and possessed the same qualification (Table 1). Participants' teaching experience differed, and could provide valuable data in relation to their experience in the use of

TABLE 1: Profile of the participants.

\begin{tabular}{|c|c|c|c|}
\hline Description & Teacher A & Teacher B & Teacher C \\
\hline School & A & B & C \\
\hline Age & 40 years & 51 years & 29 years \\
\hline Gender & $\mathrm{F}$ & $\mathrm{F}$ & $\mathrm{F}$ \\
\hline Qualification & $\begin{array}{l}\text { Certificate in ECE } \\
\text { Part-time Diploma in } \\
\text { Education programme } \\
\text { in progress }\end{array}$ & $\begin{array}{l}\text { Certificate in ECE } \\
\text { Part-time Diploma in } \\
\text { Education programme } \\
\text { in progress }\end{array}$ & Certificate in ECE \\
\hline $\begin{array}{l}\text { Teaching service in } \\
\text { ECCD centres in } \\
\text { number of years }\end{array}$ & 5 years & 18 years & 4 years \\
\hline $\begin{array}{l}\text { Teaching service in } \\
\text { reception (Grade R) } \\
\text { classes in number } \\
\text { of years }\end{array}$ & 10 years & 8 years and 9 months & 2 years \\
\hline $\begin{array}{l}\text { Number of learners } \\
\text { in the participant's } \\
\text { Grade R class }\end{array}$ & 30 & 30 & 34 \\
\hline
\end{tabular}


curriculum and hence would influence their approach to implementing policies (Bongco \& David 2020). Two participants had 30 learners in their classes, with the third having 34 . These numbers seem to be adequate for a teacher to facilitate learners' participation and to interact more with learners, especially in groups. A manageable number of learners gives teachers opportunity to maintain their attention. However, individualised attention might not be implemented effectively with the number of 30 learners and more in the class of the participants.

\section{Data generation}

The study utilised different qualitative data generation methods, specifically interviews, observations and document analysis. These also included the use of videotapes and audio-recordings to collect, store and transcribe data (Creswell \& Creswell 2018). The three observations and six interviews took place in the classroom context to acquire an in-depth understanding of the situations in Grade $\mathrm{R}$ reading lessons. Knowledge was generated through interactions with the participating teachers (epistemology) (Creswell \& Creswell 2018; Thanh \& Thanh 2015). The main purpose of early-literacy lessons is to provide Grade R learners with basic reading skills. Therefore, the study was successfully carried out in the presence of the participants and learners in the classrooms to explore the challenges and opportunities of implementing policies for teaching learners to read. The learners, however, were not direct participants in this study.

Document analysis as a method of data generation was used to generate qualitative data that involved analysis of content from written documents (Creswell \& Creswell 2018). These documents, as sources of data, refer to 'a range of written, visual and physical materials pertinent to the research

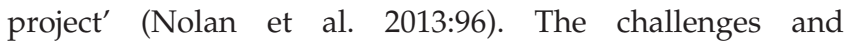
opportunities in the teaching of pre-reading in literacy lessons in Grade R classrooms may be related to documents that teachers consulted (and relied upon) that are supposed to provide effective reading instruction guidelines. In this study, documents such as policy guidelines, lesson plans, schemes of work and concrete teaching and learning materials were sources of data that provided answers to the research questions. Documents may, however, be factual, deceptive, ambiguous or inaccurate (Creswell \& Creswell 2018). In order to avoid this, participants were asked questions about the studied documents during interviews sessions. These included questions on how the documents were written, what their value is, and the applicability of the policy/curriculum guidelines, and about participants' lesson planning and implementation of policy in the classroom.

Permission from the university, the education authorities and participating schools and teachers was sought and granted to generate data in the schools, as Creswell and Creswell (2018) and Daniel (2016) asserted that participants should be informed that they have rights that should be respected.

\section{Analysis}

The instrument of qualitative content analysis was utilised in this study because it facilitated the dissecting of texts and responses of the interviewed participants (Yin 2018). This method was therefore appropriate because Grade $R$ teachers were asked open-ended questions during the interviews. Each of the three teachers was interviewed about the guidance of the regulatory guideline and about how they implement them for the teaching of basic reading skills in their classrooms. Then they were directly observed in a non-participatory teaching learners (not direct participants) observation to read in order to ensure the trustworthiness of data generated through interviews. As Yin (2018) suggested that it is essential to analyse the case study data immediately after the data generation process is commenced, therefore each of the participants' interviews was analysed separately. Note taking was also done during lesson observations. In the next step, cross-case analysis of the three case studies was carried out. It is important to note that these qualitative data of interviews, observed reading lessons and document analysis were recorded and interpreted on an ongoing basis, starting from the first visit to the classroom and ending in the last visit. We first transcribed the recordings of the interviews and thereafter interpreted the data to be well understood. The Codes and Coding techniques were used in order to link data back to the research questions and to identify common themes as thematic analysis method was used in this study. Since data analysis is a continuous process (Creswell \& Creswell 2018; Leedy \& Ormrod 2013), we continuously analysed data even after the last day of the data collection in the schools.

Data presentation involved using extracts taken from the coded data to substantiate research findings. We started with the presentation and analysis of the regulatory content in guidelines and policies for the teaching of reading in Lesotho Grade R classes. Thereafter, the presentation and interpretation of data were done case by case.

\section{Findings of the study}

This section identifies and interprets the regulatory frameworks that guide teaching in Grade $\mathrm{R}$, with the intention of answering the research question mentioned earlier in this study. Analysis of the approaches to implementing mother-tongue-instruction policy as well as the generated themes related to the following aspects: availability, access and utilisation of the guidelines and policy, teachers' understanding of the regulatory guidelines and policy, availability and utilisation of the resources, and the availability of support structures. The key findings of this study are that participating teachers in this study were willing to implement mother-tongueinstruction policy and policies for the teaching of prereading skills in Grade $\mathrm{R}$ classes, but were, however, not provided with hard and soft copies of the policy for the IECCD document in their classrooms, a policy that 
stipulates the medium of instruction. Although they did not have policy for the IECCD, they had syllabus to guide them on the teaching of basic reading skills in Grade $\mathrm{R}$ classes.

The documents which the discussion focuses on are the 'Lesotho Constitution of 1993, the Lesotho Education Act (2010), the Education Sector Plan, the National Policy for IECCD, the IECCD strategic plan 2013 and $2014-2017$ and 2018 which now extends to 2023, the Lesotho 'Early Childhood Development Curriculum 1998' and the reception (Grade R) class syllabus 2011 (Table 2).

\section{Lesotho's education policy frameworks}

Analysis of the general data from the legal frameworks (Table 2) shows that Lesotho's Constitution 1993 (s. 28) (LGCM 1993) and the Education Act 2010 (Government of Lesotho [GoL] 2010) stipulate the explicit goal of the GoL to make education accessible to all children of Lesotho. Therefore, information concerning preschools is enshrined in the Constitution, which underpins fundamental principles on education (Merriam-Webster 2019). However, these legal frameworks show that although Lesotho endeavours to make education available to all, it seems that its main focus is on the education system starting from the primary school level. It is only the Grade R syllabus that guides teachers about teaching learners basic reading skills. This is why the present study intended to explore the teachers' experiences and practices of implementing the mother-tongue policy guidelines in the teaching of reading in Grade R.
Lesotho MOET (2013a) indicated that the IECCD policy recognises that the medium of instruction in the early childhood centres, which includes the Grade R class, should be the learners' mother tongue (Table 2). The two official languages of Lesotho are Sesotho and English. Although there are other languages such as IsiXhosa, Sephuthi and IsiZulu, which are spoken by the minority groups, Sesotho is regarded as the HL that is used in all IECCD services (Lesotho MOET 2013a). According to the policy, the HL (Sesotho) should be used to present the educational materials because it is the language that parents most likely understand (Lesotho MOET 2013a). In this regard, the policy recognises that parental involvement in the learners' education is necessary (Lesotho MOET 2013a). The IECCD policy states that:

[O]ver $99 \%$ of the population is Basotho, with a few [other] ethnic groups such as the Xhosa, Baphuthi and Ndebele, [yet] the spoken languages of Lesotho are Sesotho and isiXhosa. (Lesotho MOET 2013a:26)

Therefore, the two languages that are regarded as official languages, especially Sesotho, tend to dominate the minority languages. Learners from the minority groups in the country often do not learn to read in their mother tongue (Brock-Utne 2012; Okebukola et al. 2013). This is also likely to be a challenge to the teachers because they are also not taught to read and to teach in these languages. One of the objectives of the Grade R syllabus is to ensure that learners learn to use basic language skills to communicate effectively (Lesotho MOET 2011).

TABLE 2: Legal documents and policies that provided the data.

\begin{tabular}{|c|c|c|c|}
\hline Document & General data emerging from documents & Key principles related to preschools & $\begin{array}{l}\text { Expectations from teachers in } \\
\text { preschools }\end{array}$ \\
\hline $\begin{array}{l}\text { Lesotho's Constitution-Government } \\
\text { Constitutional Matters (LGCM 1993: } \\
\text { s. 28), (LGCM 1993:27) }\end{array}$ & $\begin{array}{l}\text { Provision of education: Lesotho shall endeavour to } \\
\text { make education available to all and shall adopt } \\
\text { policies aimed at securing that primary education is } \\
\text { compulsory and available to all. }\end{array}$ & & \\
\hline $\begin{array}{l}\text { Education Act 2010- Government of } \\
\text { Lesotho (GoL) }(2010: 163,167)\end{array}$ & $\begin{array}{l}\text { Purpose and objectives of the Act: (C) make } \\
\text { provision for education for all in accordance with } \\
\text { the provisions of s. } 28 \text { of the Constitution. }\end{array}$ & $\begin{array}{l}\text { (3) The Minister shall register schools according to the } \\
\text { following: } \\
\text { a. Pre-school, which provides up to } 4 \text { years of ECE; } \\
\text { b. Junior school, which provides pre-school and } \\
\text { primary school education. }\end{array}$ & \\
\hline $\begin{array}{l}\text { The Education sector plan 2016-2026 } \\
\text { (Lesotho MOET 2016:40-41) }\end{array}$ & $\begin{array}{l}\text { Strategic objective: to review and revise current } \\
\text { preschool curricula and educational materials and } \\
\text { methods. }\end{array}$ & Goal: Improved quality of IECCD learning programmes. & \\
\hline $\begin{array}{l}\text { The National Policy for Integrated } \\
\text { Early Childhood Care and } \\
\text { Development (NPECCD/ECCD) } \\
\text { (Lesotho MOET 2013a:27, 63). }\end{array}$ & $\begin{array}{l}\text { Objective: Develop and improve the quality of } \\
\text { preschool curricula to encourage the use of } \\
\text { culturally, linguistically and age-appropriate } \\
\text { educational materials and active teaching methods } \\
\text { to stimulate child development (Lesotho MOET } \\
\text { 2013a:63). }\end{array}$ & $\begin{array}{l}\text { Population by ethnicity and language: 'Sesotho and } \\
\text { English are the two official languages of Lesotho, } \\
\text { although it is recognised that early childhood services } \\
\text { must be provided in the mother tongue to ensure } \\
\text { families shall participate fully in them and shall } \\
\text { understand educational materials' (Lesotho MOET } \\
\text { 2013a:27). }\end{array}$ & $\begin{array}{l}\text { To use culturally, linguistically } \\
\text { and age-appropriate educational } \\
\text { materials; to use active teaching } \\
\text { methods to stimulate child } \\
\text { development. }\end{array}$ \\
\hline $\begin{array}{l}\text { The Integrated Early Childhood Care } \\
\text { and Development (IECCD) Strategic } \\
\text { Plan 2013/14-2017/18 which now } \\
\text { extents to 2023 (Lesotho MOET } \\
\text { 2013b:29). }\end{array}$ & $\begin{array}{l}\text { Strategy 4: Improve and expand preschool services } \\
\text { (including home-based and reception year services) } \\
\text { for children 3-5 years, and improve transition from } \\
\text { home and preschool to primary school. }\end{array}$ & $\begin{array}{l}\text { Objective: Reinforce existing education policies for } \\
\text { preschool education to provide a strong foundation for } \\
\text { learning through offering high-quality preschool } \\
\text { education throughout Lesotho. }\end{array}$ & $\begin{array}{l}\text { Conceptual approach to IECCD: } \\
\text { rAll IECCD services will be } \\
\text { child-centred, focusing on the } \\
\text { individual needs of each child. }\end{array}$ \\
\hline $\begin{array}{l}\text { Lesotho ECD Curriculum } 1998 \\
\text { (Lesotho MOET 1998:6). }\end{array}$ & $\begin{array}{l}\text { Section 2: The major policy articulated by } \\
\text { Government with respect to early childhood } \\
\text { education is that all children between the ages of } \\
\text { two and six should have access to such education by } \\
\text { the year } 2000 .\end{array}$ & $\begin{array}{l}\text { One of the broad objectives of the curriculum: to } \\
\text { develop the knowledge and skills of both the ECCD } \\
\text { teachers and other stakeholders to plan, design, } \\
\text { implement and evaluate a child-based curriculum } \\
\text { within the context of the educational aims and goals } \\
\text { of Lesotho. }\end{array}$ & $\begin{array}{l}\text { A teacher is the key actor to } \\
\text { ensure that appropriate learning } \\
\text { takes place. } \\
\text { A teacher is expected to use } \\
\text { child-centred teaching approach } \\
\text { and play-centred learning. }\end{array}$ \\
\hline $\begin{array}{l}\text { Reception (Grade R) class syllabus } \\
2011 \text { (Lesotho MOET 2011:2) }\end{array}$ & $\begin{array}{l}\text { Purpose: In the absence of such guidelines, many } \\
\text { Reception class caregivers continually find } \\
\text { themselves forced to teach content taught in the } \\
\text { standard } 1 \text { (Grade 1) class of primary school level. }\end{array}$ & $\begin{array}{l}\text { One broad objective of the reception class is that } \\
\text { children should be able to apply language skills in } \\
\text { communicating effectively. }\end{array}$ & $\begin{array}{l}\text { Model reading skills. } \\
\text { Teach content relevant to } \\
\text { reception classes. }\end{array}$ \\
\hline
\end{tabular}

MOET, Ministry of Education and Training; ECD, Early Childhood Development; ECE, early childhood education. IECCD, Integrated Early Childhood Care and Development. 
The key principle in the Lesotho ECD Curriculum 1998 is that ECE needs to be child-centred (Lesotho MOET 1998). This document stipulates that ECCD teachers and other stakeholders should have the necessary knowledge to participate in the designing, implementation and evaluation of a child-based curriculum. How professional development of ECCD teachers is structured to enable them to implement these policy prescriptions becomes an interesting ground to explore. The current Grade $\mathrm{R}$ syllabus suggests that the classroom activities that model reading skills through scaffolding are encouraging.

\section{Challenges to access the guidelines and policy documents for teaching}

The participants knew of the existence of the policies/ guidelines, but did not have them in their classrooms. This was evident when they could not provide the IECCD policy to the researcher during lesson observations. The bulk of the regulatory guidelines that they used for their lesson preparation and teaching were derived from the Grade $R$ syllabus. The responses of the participants were common:

'I heard about the IECCD policy. I am not sure whether it is stil for Grade R class. At first, I thought it is for the home-based and community-based centres. We were workshopped about the policy. Ka utloisisa hore (I understood that) I was invited because the reception class is still preschool like other centres. I don't have it.' (Teacher A)

'I just know that there is a policy, but I have never seen it. I used a handout that summarised policy at ... LCE [Lesotho College of Education]. I was lucky that I was a student at the college, nka be ke sa tsebe letho ka policy (I would not know anything about the policy).' (Teacher B)

'The area resource teachers [ARTs] tell us what the policy needs from us, especially when we open a new preschool. There was also a course that taught us about the IECCD policy at the college.' (Teacher C)

The participants obtained guidance about the IECCD policy and its implementation through workshops held by the MOET, most often through ARTs. Mrs Mahopolang and Mrs Matebello also gained knowledge about policy from the Teacher Training College when they were students. These sources of information about policy place the three participants in a better position to implement the policy in the classroom. However, the participants do not have adequate knowledge about the policy as they were not consulted during its formulation, as in other countries, and lack adequate support from all educational stakeholders (Ntumi 2016).

\section{Sense-making of the guidelines and policies}

The interpretation of the guidelines and policies is a theme that addresses the research questions of this study. The guidelines and policies refer collectively to the curriculum, the syllabus, the IECCD policy and preparation for classroom teaching. Therefore, the cases show how the participants interpret the curriculum, the syllabus, the IECCD policy and their own preparation in order to implement mother-tongueinstruction policy in teaching reading. The data were obtained from each participant's scheme of work and lesson preparation book through document analysis and interviews and lesson observations.

The participants were asked to explain what the policy says about medium of instruction in Grade R classrooms. Teacher A responded:

'All the learners in this school speak English ... u utloile ha u kena mona bana ba ka ba bua sekhooa (You heard when you entered here that my children speak English). They don't have a problem ... That's why motsoali e mong le e mong le ba hole ba tlisang bana ba bona. Ba rata bana ba buang sekhooa (parents, even from far, send their children to this school. They like children to speak English).'

From the extract above, it seems that Teacher A and her school have made a decision to teach learners in English. They see this as a good way of attracting parents to send their learners to their school, as their analysis suggests that local parents like their children to speak English (Navarro et al. 2016). When asked why she did not teach in the HL of Sesotho, she commented:

'Policy is a policy, empa (but) it is me who have to do good work in the classroom. I don't think it is a must that I have to teach in the home language (Sesotho) in the reception (Grade R) class as it was suggested at the workshops that pre-school learners are supposed to be taught in Sesotho ...'

Teacher A holds a strong belief that she needs to contextualise whatever she was taught at the workshops. Her perception of the IECCD policy was that the suggested teaching idea in the policy was not cast in stone; what matters was that she was teaching effectively (Okebukola et al. 2013). She continued with her narrative and said:

'I don't think policy stops me from teaching in English and that it will not be simple to stop teachers to teach in English because most of the schools teach in English, even in ECCD [Early Childhood Care and Development] Centres. Children are young, bo (even) three years old. I taught them in English and they understood. Policy should allow us to teach in both languages molemong oa bokamoso ba thuto e ntle ea bana (for the children's future educational benefit).'

The emphasis from this narrative by Teacher $\mathrm{A}$ is that although the IECCD policy recognises the native language as the medium of instruction in Grade R, it does not stop her from choosing to teach in English. She clearly had no intention to stop teaching the learners in English, as she indicated that most of the schools teach in English. According to her, the IECCD policy is not prescriptive to stop other teachers to teach in English (Okebukola et al. 2013). Her belief seems to be that when learners are taught in English from an early age (three), they are able to understand what is taught in class in that language. In other words, she seems to argue that even second-language speakers are able to acquire first-language competence with early exposure and consistent reinforcement and practice. Her firm understanding was that the IECCD policy should 
give her and other teachers the flexibility to teach prereading skills in Grade $R$ in both languages in order to prepare young learners for the best academic achievement in the higher grades. However, it was observed that she spoke both Sesotho and English (mostly English), sometimes code-switching during lessons, even though she claimed that English is her medium of instruction. She was observed teaching letters of the alphabet and phonological awareness and emphasised English sounds.

Teacher B, also explained what the policy says about medium of instruction in Grade R classrooms:

'The principal wants me to teach in English. Sekhooa e se e le sona hohle mona. O bona batho bohle ba se nketse holimo (English is key everywhere. As you may be aware, all the people seem to hold it in high regard). Even the syllabus does not say I should teach in Sesotho or in English, but I know I have to teach in the home language, ke hore (that is to say) in Sesotho. Look, sir, letters of the alphabet is not Sesotho ...'

Teacher B understood that although the IECCD policy recognises Sesotho as the medium of instruction in Grade $R$ classes, she had to respect and take into consideration the views of the community and the principal by teaching her learners in English (Hallam et al. 2015; Mashiya 2011). This suggests that she had to align herself with the goals or policies of the school as well. She had to make choices that would benefit her learners, the community and the school. Her responses were confirmed in almost all the lessons. She was observed code-switching between Sesotho and English especially when naming objects and pictures. She emphasised initial sounds. In two of the lessons, she taught learners parts of a plant which were labelled in English only. She taught learners to read letters that formed those words and to read words.

This is what Teacher C had to say:

'Sir, boholo ba lintho (most of the things/materials) are written in English ... I teach in Sesotho and sometimes in English because likolo tse haufi (the nearby schools) teach children to read English ... ha ke batle ho sala ke le mong batsoali batla ntsa bana (I don't want to be left alone as parents will take their children out of this school) ... Re rutuoe hore (We have been taught that) the policy says we should teach in Sesotho.'

It is evident that Teacher C was exposed to the policy and she understood that she should teach the learners to read Sesotho, but her biggest challenge was that she does not have adequate teaching and learning materials to adhere to the policy. Most of the materials that she had access to are written in English. Her story captures the constant struggle to grasp the new policy. She tried her best to teach in her $\mathrm{HL}$, even though her classroom instruction was also influenced by the community and by what went on in the nearby schools. As a result, she taught learners to understand both Sesotho and English during lessons with English being dominant language as it was verified in her lesson plans (Vilches 2018).

\section{Discussion of the findings}

We sought to explore the implementation of mother-tongueinstruction policy in ECE in Lesotho, particularly for the teaching of reading in Grade $\mathrm{R}$. This section presents a discussion on the most important findings.

\section{Recognition of language diversity in mother- tongue-instruction policy}

This study found that the IECCD policy announces that the medium of instruction in the early childhood centres should be the learners' mother tongue (Lesotho MOET 2013a). The policy states that the two official languages are Sesotho and English, though there are other languages that are spoken by the minority groups. However, Sesotho is regarded as the HL that is used in all IECCD services because the majority of the population of Lesotho is Basotho and the dominant language of the minority groups (Lesotho MOET 2013a). Although the policy recognises the existence of other languages in the country, it is evident that learners from the minority groups in the country often do not learn to read in their mother tongue. Their mother tongue has no part to play in the education system. Even if the teachers are willing to implement mother-tongue-instruction policy, they would probably be challenged to do so because they are nonminority-language speakers and have never been taught in these languages nor trained to teach minority languages spoken in Lesotho. This finding adds to the finding by Mashiya (2011) that teachers failed to implement language policy well because they are not conversant with the language of teaching and learning. Implementing mother-tongueinstruction policy, as it is currently, would put minority group learners who are not Sesotho or English HL speakers at disadvantage.

\section{Teachers' limited participation in policy design}

The finding of this study was that teachers were not adequately informed about the policy implementation as they were not involved in the infancy stage of its design. One of the reasons teachers do not implement mother-tongueinstruction policy effectively when teaching pre-reading skills was that they are limited in their participation in the policy design. This finding corroborates with the finding of Dube and Jita (2018) that teachers are not adequately involved in the design of new curriculum policy. Teachers being the implementers, their involvement is important for successful and meaningful policy design and implementation.

\section{Integrated early childhood care and development policy: Accessibility of policy documents}

Another key findings of this study was that the participating Grade $\mathrm{R}$ teachers struggled with mother-tongue-instruction policy when teaching learners pre-reading skills because they had not accessed the IECCD policy and relied on informal and verbal information. The MOET had never supplied them with copies of the policy document. The 
information that they have about the IECCD policy was obtained mostly through the dissemination workshops and the teacher-training college when they attended them earlier. The study found that the policy is an important document that needs to be available in the Grade R classrooms in order to provide teachers with guidance. A similar observation was made by Bongco and David (2020) and Mueller and File (2019) that teachers do not implement the curriculum effectively in part because they are not provided with the relevant resources.

\section{Medium of instruction}

It is evident from the document analysis, lesson observations and from the interaction with the three participants that the language policy was one such instance of the guidelines written in the IECCD policy. However, the participants continued to use Sesotho and English in their teaching the learners to read in English, signalling that mother tongue instruction paves a good foundation for English literacy skills. The findings of this study indicated that teachers' understanding was that codeswitching helps them to develop language, communication and reading skills of learners. They code-switched partly because they were not clear on the policy, but also because the context made implementation difficult, if not impossible. This finding aligns with the finding of Okebukola et al. (2013) that teachers use both the mother tongue and English as medium of instruction even when the language policy recognises the mother tongue as the language of teaching in the classroom.

Participants used both Sesotho and English when teaching learners to satisfy the principal who wants them to teach the learners in English and to also satisfy the parents, despite the fact that the IECCD policy prescribes Sesotho as the medium of instruction in Grade $\mathrm{R}$ classrooms. According to the findings by Dube and Jita (2018), the relationship between teachers and the administrative section becomes negatively affected when teachers are forced to implement curriculum changes that they are not knowledgeable about. Nonetheless, this friction was not the case in this study. Participants did not possess adequate knowledge of the policy and hence followed the views of the principal. On the other hand, this finding of the study confirms what Samson and Charles (2018) have observed, that principals' inappropriate response to curriculum reform and supervision of curriculum implementation is because of the lack of information and training. The principals want the teachers to teach in English (in addition to the HL) because the neighbouring schools teach in English. A further reason, according to Mrs Matebello, was that most of the learning materials are written in English.

\section{Lack of teaching and learning materials}

Although Grade R classes were recently incorporated into primary schools for the purpose of achieving the objectives of Education for All by the GoL, they are not supplied with the required resources and essential teaching and learning materials, such as books. This indicates the scarcity of the essential teaching and learning materials for the teaching of basic reading skills and policy implementation in Lesotho Grade $\mathrm{R}$ classes. The study confirmed the findings of Hudson et al. (2019) that teachers who do not have the necessary teaching and learning materials are unable to implement the syllabus successfully. The unavailability of books, especially those that facilitate mother tongue instruction, in the classroom hinders effective policy implementation.

\section{Grade R syllabus}

One other attention-grabbing finding of this study was that the recent Grade R syllabus does not have any section suggesting a language that teachers must use to teach learners to read. For instance, Teacher B knew that the policy may require her to teach in the HL, but she made her point strongly when she referred to the letters of the alphabet, suggesting that these are not taught in Sesotho. Participants had their reasons for teaching in both mother tongue and a foreign language, Sesotho and English in the case of Lesotho. They decide to code-switch between languages to meet the learners' needs in the classroom because they have a challenge to accommodate all the learners in English instruction (Okebukola et al. 2013).

The most important part concerning the findings of this study is that it employed case studies in qualitative research, which created opportunities for us to understand participating teachers' personal experiences in their real context. For further study in future, it will be more advantageous to generate data from many Grade $\mathrm{R}$ teachers using a quantitative research method.

\section{Conclusion}

Findings from this study showed that mother-tongueinstruction policy recognises Sesotho language as a HL that should be used in ECE. Although it recognises the existence of other languages of few ethnic minority groups that form Basotho nation, it does lift up the use of them in the classrooms. Learners from these groups are currently denied opportunity to learn to read in their mother tongue because the policy ignores their existence in the education system and teachers are not taught to teach in those languages. The education system of Lesotho has not yet responded fully to the demand of mothertongue-instruction policy as it happens globally (Okebukola et al. 2013).

Grade $\mathrm{R}$ teachers are willing to implement the regulatory guidelines and policies for teaching in classes even though they struggle to do so because of various challenges relating to limited knowledge, ecological factors and inadequate support. There are parents who want their children to be taught in English language. This finding corroborates with the finding of Mashiya (2011), who observed that parents in 
KwaZulu-Natal want their children to be taught in English, their first additional language, in the foundation phase classroom even when the language education policy advocates the use of mother tongue instruction. This aligns with the finding by Bongco and David (2020) that teachers struggle to implement curriculum policy, yet they find ways to achieve the goals of the changed initiatives. This finding also matches the finding by Chimbi and Jita (2019) and Ntumi (2016) that there are teachers who are willing to implement curriculum but lack professional development and therefore lack knowledge on the interpretation and implementation of the new curriculum. This study provided evidence that the participants were not resistant to change, which adds to the existing findings by Alieto (2019) and Chimbi and Jita (2019) that teachers are progressive and revolutionary and move in the direction of implementing developments in the curriculum policy.

This study concludes that many schools have made a decision to teach learners in English as early as in early childhood. This is because some of the Basotho people, if not all, want their children to be taught in English in Grade R classes as indicated by the participants during interviews. People believe that knowledge of English language creates many life opportunities (Alieto 2019; Gumbi \& Ndimande-Hlongwa 2015). These perceptions influence teachers' choice of the medium of instruction to be contrary to what the national IECCD policy on medium of instruction stipulates. As a result, teachers' understanding is that it is not obligatory to implement mother-tongue-instruction policy as it is. They were also observed code-switching with the purpose of satisfying the community and meeting learners' language learning needs during lessons.

\section{Recommendations}

Based on the findings of this study, we recommend that the teachers in ECE should communicate with policymakers and share ideas about effective implementation of mothertongue-instruction policy in all ethnic groups. Linguistic diversity should be taken into consideration in schools. The policy should recognise the existence of languages of ethnic minority groups living in Lesotho. This study suggests that even if Sesotho and English are currently recognised as the official languages, they should not be the only languages used as medium of instruction in the country, especially in ECE. Learners of the different linguistic minority groups also have to be fluent in their mother tongue. There should be adequate support from all the stakeholders who have interest in ECE. This includes provision of relevant teaching and learning materials in ECCD centres and classes up to Grade 3 , which are said to be foundation phase classes (Lesotho MOET 2013).

The study uncovered that the IECCD policy, in which language of teaching in ECE is stipulated, is disseminated orally to the teachers and therefore they do not have the physical policy document in their classrooms. There is a need for workshops to familiarise Grade $\mathrm{R}$ teachers with the policy (Lesotho MOET 2013) and to provide them with hard and soft copies of the policy documents. Whether it is mandatory that Grade R learners should be taught in the mother tongue or not has to be clarified.

The MOET, through the ECCD Unit, the National Curriculum Development Centre (NCDC) in collaboration with teachereducation institutions and any other stakeholders interested in ECE, should provide professional development for Grade $\mathrm{R}$ teachers through workshops and seminars. They should organise regular centre or area visits in schools to monitor the implementation of the syllabus and policy guidelines. Although the ARTs already hold workshops for teachers to inform them about policy, as participants indicated, we suggest that they should also hold frequent workshops which are intended to improve the quality of instruction, including language of teaching. Research paralleling the findings of this study (Chimbi \& Jita 2019; Ntumi 2016) indicates that teachers need ongoing training to implement the curriculum effectively.

The participating Grade R teachers' willingness to implement mother-tongue-instruction policy signifies a need for adequate support from all the stakeholders. This issue of support adds to Dube and Jita (2018) and Hudson et al.'s (2019) contention that inadequate communication and collaboration among educational stakeholders results in unfavourable effects on curriculum and policy implementation. Henceforth, there is a need for positive relationship amongst stakeholders for successful implementation of curriculum and education policies.

This study recommends that the MOET and policymakers have to monitor and facilitate the implementation of language of teaching policy, especially in ECE. They should establish a national advocacy campaign to orientate people to the notion of the language of teaching policy and the whole purpose of investing in ECE. Policymakers should give substantial guidance to all the stakeholders in ECE on how to effectively implement this policy in practice. Everybody nationwide should exert full commitment to instruction policy implementation in order to continuously improve the quality of education.

\section{Acknowledgements}

No one was involved in the write up of this article except the authors. This work was supported by the South African National Roads Agency Limited (SANRAL) chair office at the University of the Free State.

\section{Competing interests}

The authors declare that they have no financial or personal relationship(s) which may have inappropriately influenced them in writing this article.

\section{Authors' contributions}

A.C.K as the principal investigator in his Master's research carried out research, collected data, analysed data and 
interpreted the results under the supervision of T.J. T.J. provided technical guidance for all aspects for writing the article, and reviewed and edited it. Both the authors read and approved the final version of the manuscript.

\section{Ethical considerations}

Permission to conduct research in schools was sought and granted by the ethical clearance committee of the University of the Free State, the Lesotho district education authorities, principals of participating schools and teachers who participated in the study. UFS-HSD2017/0967

\section{Funding information}

This research comes out of the Masters' thesis at the University of the Free State and was supported by the Thuthuka National Research Foundation (NRF reference number: TTK170405225946).

\section{Data availability}

There are no accession codes, web links, figures and any restrictions related to raw data used in this study.

\section{Disclaimer}

The ideas expressed in this article are those of the authors' and are not influenced by the policies of the affiliated institution/s.

\section{References}

Alieto, E.O., 2019, 'Cognition as predictor of willingness to teach in the mother tongue and the mother tongue as a subject among prospective language teachers', Online Submission 31(1B), 135-139.

Blake, B. \& Pope, T., 2008, 'Developmental psychology: Incorporating Piaget's and Vygotsky's theories in classrooms', Journal of Cross-disciplinary Perspectives in Education 1(1), 59-67.

Bongco, R.T. \& David, A.P., 2020, 'Filipino teachers' experiences as curriculum policy implementers in the evolving K to 12 landscape', Issues in Educational Research 30(1), 19-34.

Brock-Utne, B., 2012, 'Language policy and science: Could some African countries learn from some Asian countries?', International Review of Education 58(4), 481-503. https://doi.org/10.1007/s11159-012-9308-2

Cekiso, M., Meyiwa, T. \& Mashige, M., 2019, 'Foundation phase teachers' experiences with instruction in the mother tongue in the Eastern Cape', South African Journal of Childhood Education 9(1), a658. https://doi.org/10.4102/sajce.v9i1.658

Chimbi, G.T. \& Jita, L.C., 2019, 'Willing but unable? Teachers' sense-making of curriculum-reform policy in the early implementation stage', Pedagogika 135(3) 52-70. https://doi.org/10.15823/p.2019.135.3

Creswell, J.W. \& Creswell, J.D., 2018, Research design: Qualitative, quantitative, and mixed methods approaches, 5th edn., Sage, London.

Daniel, E., 2016, 'The usefulness of qualitative and quantitative approaches and methods in researching problem-solving ability in science education curriculum Journal of Education and Practice 7(15), 91-100.

Department of Basic Education (DBE), 2011, Curriculum and assessment policy statements (CAPS), Department of Basic Education, Pretoria.

Dube, B. \& Jita, T., 2018, 'Rethinking healthy school relations for curriculum change in Zimbabwe: A relational leadership approach', Issues in Educational Research 28(4), 901-917.

Ekanjume-llongo, B., 2015, 'The teaching of English as a second language: The case of the National University of Lesotho (NUL)', Journal of Language Teaching and Research 6(6), 1157-1164. https://doi.org/10.17507/jltr.0606.01

Gumbi, P. \& Ndimande-Hlongwa, N., 2015, 'Embracing the use of African languages as additional languages of teaching and learning in KwaZulu-Natal schools', South African Journal of African Languages 35(2), 157-162. https://doi.org/10.1080/02 572117.2015.1112999
Hallam, P.R., Smith, H.R., Hite, J.M., Hite, S.J. \& Wilcox, B.R., 2015, 'Trust and collaboration in PLC teams: Teacher relationships, principal support, and collaborative benefits', NASSP Bulletin 99(3), 193-216. https://doi.org/10.1177/ 0192636515602330

Hudson, B., Hunter, D. \& Peckham, S., 2019, 'Policy failure and the policyimplementation gap: Can policy support programs help?', Policy Design and Practice 2(1), 1-14. https://doi.org/10.1080/25741292.2018.1540378

Kao, M.A. \& Mzimela, P.J., 2019, “'They are visually impaired, not blind ... teach them!": Grade R in-service teachers' knowledge of teaching pre-reading skills to visually impaired learners', South African Journal of Childhood Education 9(1), a651. https://doi.org/10.4102/sajce.v9i1.651

Leedy, P.D. \& Ormrod, J.E., 2013, Practical research planning and design, 10th edn., Pearson, London.

Lenyai, E., 2011, 'First additional language teaching in the foundation phase of schools in disadvantaged areas', South African Journal of Childhood Education 1(1), 68-81. https://doi.org/10.4102/sajce.v1i1.76

Lesotho Education Act 2010, 2010, Government Gazette extraordinary, Government Printers, Maseru.

Lesotho Government Constitutional Matters (LGCM), 1993, The Constitution of Lesotho, Government Printers, Maseru.

Lesotho Ministry of Education and Training (MOET), 1998, Lesotho early childhood development curriculum, Ministry of Education and Training, Maseru.

Lesotho Ministry of Education and Training (MOET), 2011, Reception class guidelines, Ministry of Education and Training, Maseru.

Lesotho Ministry of Education and Training (MOET), 2013a, National policy for integrated early childhood care and development, Ministry of Education and integrated early
Training, Maseru.

Lesotho Ministry of Education and Training (MOET), 2013b, National strategic plan for integrated early childhood care and development 2013/2014-2017/2018, Ministry of Education and Training, Maseru.

Lesotho Ministry of Education and Training (MOET), 2016, Education sector plan 2016-2026, Lesotho Ministry of Education and Training (MOET), Maseru.

Malebese, M.L., Tlali, M.F. \& Mahlomaholo, S., 2019, 'A socially inclusive teaching strategy for fourth grade English (Second) language learners in a South African school', South African Journal of Childhood Education 9(1), a503. https://doi. org/10.4102/sajce.v9i1.503

Mashiya, N., 2011, 'IsiZulu and English in KwaZulu-Natal rural schools: How teachers fear failure and opt for English', South African Journal of Childhood Education 1(1), 19-31. https://doi.org/10.4102/sajce.v1i1.71

Merriam-Webster, 2019, Learner's dictionary, viewed 12 September 2019, from http://www.learnersdictionary.com.

Mueller, J.J. \& File, N. (eds.), 2019, Curriculum in early childhood education: Re-examined, reclaimed, renewed, Routledge, New York, NY.

Mukherji, P. \& Albon, D., 2015, Research methods in early childhood: An introductory guide, 2nd edn., Sage, London.

Navarro, T.M.M., Abao, E.L., Bacus, R.C., Alda, R.C. \& Espera, C.C., 2016, 'Mother tongue-based instruction: Policy to practice', International Journal of Education and Research 4(3), 157-172.

Nishanthi, R., 2020, 'Understanding of the importance of mother tongue learning', International Journal of Trend in Scientific Research and Development (IJTSRD) 5(1), 77-80.

Nolan, A., Macfarlane, K. \& Cartmel, J., 2013, Research in early childhood, Sage, London.

Ntumi, S., 2016, 'Challenges pre-school teachers face in the implementation of the early childhood curriculum in the Cape Coast Metropolis', Journal of Education and Practice 7(1), 54-62.

Nulden, U. \& Scheepers, H., 2020, 'Increasing student interaction in learning activities: Using a simulation to learn about project failure and escalation', Journal of Information Systems Education 12(4), 223-232.

Okebukola, P.A., Owolabi, O. \& Okebukola, F.O., 2013, 'Mother tongue as default language of instruction in lower primary science classes: Tension between policy prescription and practice in Nigeria', Journal of Research in Science Teaching 50(1) 62-81. https://doi.org/10.1002/tea.21070

Pishghadam, R. \& Ghadiri, S., 2011, 'Symmetrical or asymmetrical scaffolding: Piagetian vs. Vygotskyan views to reading comprehension', Journal of Language and Literacy Education 7(1), 49-64.

Samson, M.K. \& Charles, M.M., 2018, 'Challenges facing secondary school principals in the implementation of the National curriculum statement in Capricorn district of the Limpopo province', British Journal of Multidisciplinary and Advanced of the Limpopo provir $2(1), 60-70$.
Studi

Thanh, N.C. \& Thanh, T.T.L., 2015, 'The interconnection between interpretivist paradigm and qualitative methods in education', American Journal of Educational Science 1(2), 24-27.

Vilches, M.L.C., 2018, 'Involving teachers in the change process: One English language teacher's account of implementing curricular change in Philippine basic education', in M. Wedell \& L. Grassick (eds.), International perspectives on teachers living with curriculum change, pp. 15-37, Palgrave Macmillan, London.

Yin, R.K., 2018, Case study research and applications: Design and methods, 6th edn., Sage, London. 